\title{
From basic research to applied veterinary sciences: current status, challenges and perspectives
}

\author{
Seddik Hammad ${ }^{1,2}(1) \cdot$ Amnah Othman $^{3} \cdot$ Ahmed A. A. Abdel-Wareth $^{4,5} \cdot$ Hassan Ahmed $^{6}$. \\ Mohamed M. Abdel-Daim ${ }^{7,8}$. Youssuf A. Gherbawy ${ }^{9}$
}

Received: 18 April 2018 / Accepted: 23 April 2018 / Published online: 26 April 2018

(c) Springer-Verlag GmbH Germany, part of Springer Nature 2018

Globally, veterinary-based research is performed for two purposes. First, it is performed to better understand the molecular, genetic and phenotypic, as well as pathophysiological background of animal diseases. This discipline has a great value economically, i.e., controlling diseases (Porphyre et al. 2018), increasing animal productivity (Abdel-Wareth et al. 2014) and decreasing the required health care costs (Prinsloo et al. 2018). However, more importantly, clinically to prevent human diseases of animal origin, i.e., communicable/zoonotic diseases, food borne illness (Hassan et al. 2011), toxic residues (Mohamed et al. 2017), etc. Recently, several measures were considered to improve animal farms and health care (Jacobs et al. 2018). However, more attention should be paid to protect wild, farm and companion animals, as well as pets, from genetically modified microorganisms (Elhariry et al. 2011), toxic residues (Mohamed et al. 2017) and climate alterations (Combe et al. 2017). Moreover, vaccine development and approval of less resistible compounds, i.e., antibiotics and cancer chemotherapeutics, are the most important protective and preventative strategies (Kumar et al. 2018) and must be considered. Second, animals are

Seddik Hammad's contribution was exclusively achieved at the Faculty of Veterinary Medicine, South Valley University, Egypt.

Seddik Hammad

seddik.hammad@vet.svu.edu.eg;

seddik.hammad@medma.uni-heidelberg.de

1 Department of Forensic Medicine and Toxicology, Faculty of Veterinary Medicine, South Valley University, Qena, Egypt

2 Molecular Hepatology Section, Department of Medicine II, Medical Faculty, Mannheim Heidelberg University, 68167 Mannheim, Germany

3 Leibniz Institut für Analytische Wissenschaften-ISAS e.V., Dortmund, Germany

4 Department of Animal and Poultry Production, Faculty of Agriculture, South Valley University, Qena, Egypt intensively used as experimental models to understand the underlying mechanisms of human diseases (Nussler et al. 2014), to identify new targetable protein(s) or pathway(s) and to approve drugs preclinically (Henderson et al. 2013). In the last decades, numerous funding agencies, such as the EU, suggested that animals used in experiments must be replaced, reduced and refined - the so called 3Rs (Daneshian et al. 2015). Basically, there are two ways to achieve these ambitious goals: (1) to develop alternative wet lab-based methods, e.g., 2D cell culture (Godoy et al. 2016), 3D spheroid models (Kim et al. 2015), primary cells (Reif et al. 2015) and cell lines (Luckert et al. 2017), or (2) to use in silico computer-assisted models to answer the corresponding biological questions (Hammad et al. 2015). Despite extensive funding in the last decades for both methods, the optimal understanding of human pathophysiological events is still unmet. We do not believe that animals will be completely replaced by an alternative method; however, research is still leading in this direction every day.

Based on the aforementioned background, animal science is a significantly rich field of research. In approximately $90 \%$ of biomedical oriented articles in the last decade, experimental animals, primary cells or cell lines of animal origin were involved. Therefore, the Faculty of

5 Animal Nutrition Group, Institute of Animal Science, University of Bonn, Bonn, Germany

6 Department of Physiology, Faculty of Veterinary Medicine, South Valley University, Qena, Egypt

7 Department of Pharmacology, Faculty of Veterinary Medicine, Suez Canal University, Ismailia, Egypt

8 Department of Ophthalmology and Micro-Technology, Yokohama City University, Yokohama, Japan

9 Department of Botany, Faculty of Science, South Valley University, Qena, Egypt 
Veterinary Medicine-South Valley University, Egypt has recently launched the SVU-International Journal of Veterinary Sciences (https://portal.svu.edu.eg/svu-src/index.php/ ijvs). The scope of this journal is to cover biomedical sciences particularly in the aforementioned topics. In detail, the journal will publish articles of high quality standards in the following topics: (1) basic/conventional research oriented in experimental or case study form. This includes-but is not limited to-anatomy, histology, biochemistry, biophysics, physiology, microbiology, parasitology, nutrition, pharmacology, toxicology, forensic sciences, pathology, surgery, theriogenology, obstetrics, andrology, internal medicine, zoonotic diseases, behavior, husbandry, wild life, poultry and fish diseases, as well as food hygiene. (2) Cutting-edge articles in translational medicine, e.g., humanized models, transgenic mice (Mohamed et al. 2015; Lai et al. 2018), stem cell therapy (Godoy et al. 2015; Hammad et al. 2016) and computational medicine (Hoehme et al. 2017). This section includes up-to-date technologies of veterinary relevance, e.g., modern artificial insemination, biobanking, publically available datasets mining (Nwosu et al. 2017; Sweeney et al. 2018) and 2D/3D cell/tissue analysis (Hammad 2013). (3) Applied veterinary studies, e.g., herbal derivatives as food additives and/or protective synthetic and natural agents (Abdel-Wareth and Lohakare 2014; Prinsloo et al. 2018), nanotechnologies for drug development (Gherbawy et al. 2013; Aly et al. 2018) and compound delivery will be highly welcomed. The journal will also be enthusiastic to consider biomedical articles from biology, biomedicine and agriculture oriented disciplines. There will be no publication costs associated with this newly launched journal. In addition to the tightly controlled peer review process, the well-recognized Editors-in-Chief will accept only articles of high quality. We are sure that this newly launched journal will contribute to advancements in the veterinary sciences.

\section{References}

Abdel-Wareth AAA, Lohakare JD (2014) Effect of dietary supplementation of peppermint on performance, egg quality, and serum metabolic profile of Hy-Line Brown hens during the late laying period. Anim Feed Sci Tech 197:114-120

Abdel-Wareth AA, Hammad S, Ahmed H (2014) Effects of Khaya senegalensis leaves on performance, carcass traits, hemtological and biochemical parameters in rabbits. EXCLI J 13:502-512

Aly FM, Kotb AM, Haridy MAM, Hammad S (2018) Impacts of fullerene $\mathrm{C}_{60}$ and virgin olive oil on cadmium-induced genotoxicity in rats. Sci Total Environ 630:750-756

Combe M, Velvin CJ, Morris A, Garchitorena A, Carolan K, Sanhueza D et al (2017) Global and local environmental changes as drivers of Buruli ulcer emergence. Emerg Microb Infect 6(4):e22 (Review)

Daneshian M, Busquet F, Hartung T, Leist M (2015) Animal use for science in Europe. ALTEX 32(4):261-274
Elhariry H, Bahobial AA, Gherbawy Y (2011) Genotypic identification of Penicillium expansum and the role of processing on patulin presence in juice. Food Chem Toxicol 49(4):941-946

Gherbawy YA, Shalaby IM, El-Sadek MS, Elhariry HM, Abdelilah BA (2013) The anti-fasciolasis properties of silver nanoparticles produced by Trichoderma harzianum and their improvement of the anti-fasciolasis drug triclabendazole. Int J Mol Sci 14(11):21887-21898

Godoy P, Schmidt-Heck W, Natarajan K, Lucendo-Villarin B, Szkolnicka D, Asplund A et al (2015) Gene networks and transcription factor motifs defining the differentiation of stem cells into hepatocyte-like cells. J Hepatol 63(4):934-942

Godoy P, Widera A, Schmidt-Heck W, Campos G, Meyer C, Cadenas $C$ et al (2016) Gene network activity in cultivated primary hepatocytes is highly similar to diseased mammalian liver tissue. Arch Toxicol 90(10):2513-2529

Hammad S (2013) Advances in 2D and 3D in vitro systems for hepatotoxicity testing. EXCLI J 12:993-996

Hammad S, Omar MA, Abdallah MF, Ahmed H (2015) Perspectives of tissues in silico. EXCLI J 14:408-410

Hammad S, Mahmoud HY, Hamadneh L, Elsherief AM, MeindlBeinker NM, Kotb AM (2016) Highlight report: pluripotent stem cells in translational research. Arch Toxicol 90(12):3145-3146

Hassan SA, Altalhi AD, Gherbawy YA, El-Deeb BA (2011) Bacterial load of fresh vegetables and their resistance to the currently used antibiotics in Saudi Arabia. Foodborne Pathog Dis 8(9):1011-1018

Henderson NC, Arnold TD, Katamura Y, Giacomini MM, Rodriguez JD, McCarty JH et al (2013) Targeting of $\alpha v$ integrin identifies a core molecular pathway that regulates fibrosis in several organs. Nat Med 19(12):1617-1624

Hoehme S, Friebel A, Hammad S, Drasdo D, Hengstler JG (2017) Creation of three-dimensional liver tissue models from experimental images for systems medicine. Methods Mol Biol 1506:319-362

Jacobs C, Orsel K, Mason S, Barkema W (2018) Comparison of effects of routine topical treatments in the milking parlor on digital dermatitis lesions. J Dairy Sci. https://doi.org/10.3168/ jds.2017-13984

Kim JY, Fluri DA, Marchan R, Boonen K, Mohanty S, Singh P et al (2015) 3D spherical microtissues and microfluidic technology for multi-tissue experiments and analysis. J Biotechnol 205:24-35

Kumar A, Meldgaard TS, Bertholet S (2018) Novel platforms for the development of a universal influenza vaccine. Front Immunol 9:600 (Review)

Lai D, Teng F, Hammad S, Werle J, Maas T, Teufel A et al (2018) Hepatic Smad7 overexpression causes severe iron overload in mice. Blood 131(5):581-585

Luckert C, Schulz C, Lehmann N, Thomas M, Hofmann U, Hammad $S$ et al (2017) Comparative analysis of 3D culture methods on human HepG2 cells. Arch Toxicol 91(1):393-406

Mohamed FE, Al-Jehani RM, Minogue SS, Andreola F, Winstanley A, Olde Damink SW et al (2015) Effect of toll-like receptor 7 and 9 targeted therapy to prevent the development of hepatocellular carcinoma. Liver Int 35(3):1063-1076

Mohamed HMA, Emeish WFA, Braeuning A, Hammad S (2017) Detection of aflatoxin-producing fungi isolated from Nile tilapia and fish feed. EXCLI J 16:1308-1318

Nussler AK, Wildemann B, Freude T, Litzka C, Soldo P, Friess H et al (2014) Chronic CCl4 intoxication causes liver and bone damage similar to the human pathology of hepatic osteodystrophy: a mouse model to analyse the liver-bone axis. Arch Toxicol 88(4):997-1006

Nwosu ZC, Megger DA, Hammad S, Sitek B, Roessler S, Ebert MP et al (2017) Identification of the consistently altered metabolic targets in human hepatocellular carcinoma. Cell Mol Gastroenterol Hepatol 4(2):303-323 
Porphyre T, Rich KM, Auty HK (2018) Assessing the economic impact of vaccine availability when controlling foot and mouth disease outbreaks. Front Vet Sci 5:47

Prinsloo G, Nogemane N, Street R (2018) The use of plants containing genotoxic carcinogens as foods and medicine. Food Chem Toxicol 116:27-39. https://doi.org/10.1016/j.fct.2018.04.009
Reif R, Karlsson J, Günther G, Beattie L, Wrangborg D, Hammad S et al (2015) Bile canalicular dynamics in hepatocyte sandwich cultures. Arch Toxicol 89(10):1861-1870

Sweeney TE, Perumal TM, Henao R, Nichols M, Howrylak JA, Choi AM et al (2018) Community approach to mortality prediction in sepsis via gene expression analysis. Nat Commun 9(1):694 